Erratum

\title{
Erratum: Lawrence, D.P. Pratyabhijñā Apoha Theory, Shannon-Weaver Information, Saussurean Structure, and Peircean Interpretant Agency. Religions 9 (2018): 191
}

\section{Religions Editorial Office}

MDPI, St. Alban-Anlage 66, 4052 Basel, Switzerland

Received: 9 August 2018; Accepted: 14 August 2018; Published: 27 August 2018

Abstract: In lieu of an abstract, this is an excerpt from the first page.

Regrettably this article (Lawrence 2018) was published with a number of misprints and other errors. The manuscript will be updated and placed on the webpage along with the original version.

There should be an o in Philosphy in the statement of my affiliation with the "Department of Philosophy and Religion".

There should be a comma after Abhinavagupta in the epigraph.

On p. 2, in parentheses sattā should be in italics.

On p. 2, the sentence, "The Yogācāra Buddhist logical-epistemological tradition ... who generally advocated a kind of phenomenalism ...," should not have "who."

On p. 3, the sentence "There are also background ideas in Vedic ritualism and the grammar of vikalpa..." should not have "the" before grammar.

On p. 3, the ā should be short, and there should be a na on Śankarānanda to read Śankkaranandana.

On p. 4, Chuang 1964 should be Chuang Tzu 1964.

On p. 9, the expression "syntactio-semantic ... " should read "syntactico-semantic."

On p. 10, in the sentence "While at all levels, self-organization as information is based on difference along with ... " there should not be an "is" before "based."

On p. 12, there should be an illustration rather than words printed.

In fn. 9, two Sanskrit block quotes should be in italics.

In fn. 10, janasthiti, anusaṃdhāna, two occurrences of the word jñāna, and aparasparavedinā should be in italics.

In fn. 13, the paragraph should be indented that begins "The idea of fragmentations".

In fn. 13, one of the blockquotes in Sanskrit should be in italics.

In fn. 18, yadyayarthasthitih. prāṇapuryaṣtakaniyantrite, jive niruddhā tatrāpi paramātmani sā sthitā should be in italics.

There are numerous mistakes in the Bibliography and References, and items in the former that should be in the latter including:

Bateson, Gregory. 1972.

Chatterjee, Amita. 2011.

Heidegger, Martin. 1969.

Lawrence, David Peter. 2013b.

Pierce, John R. 1980.

Pind, Ole. 2011. 
Sanderson, Alexis. 1985.

Stcherbatsky, F. Th. Buddhist Logic. 2 vols. 1962.

\section{Reference}

Lawrence, David Peter. 2018. Pratyabhijñā Apoha Theory, Shannon-Weaver Information, Saussurean Structure, and Peircean Interpretant Agency. Religions 9: 191. [CrossRef] 